\title{
EFFICACY OF Trichoderma asperellum, T. harzianum, T. longibrachiatum AND T. reesei AGAINST Sclerotium rolfsii
}

\author{
EFICÁCIA DE Trichoderma asperellum, T. harzianum, T. longibrachiatum $E$ T. reesei \\ CONTRA Sclerotium rolfsii
}

\author{
Klênia Rodrigues PACHECO ${ }^{1}$; Bernardo Souza Mello VISCARDI ${ }^{2}$; \\ Thais Melissa Macedo de VASCONCELOS ${ }^{3}$; Geisianny Augusta Monteiro MOREIRA ${ }^{4}$; \\ Helson Mario Martins do VALE ${ }^{5}$ Luiz Eduardo Bassay BLUM ${ }^{6}$ \\ 1. Mestre, Agronomia, FAV, Universidade de Brasília - UnB, Brasília, DF, Brasil; 2. Mestre, FAV - UnB, Brasília, DF, Brasil; 3. \\ Engenheira Agrônoma, FAV - UnB, Brasília, DF, Brasil; 4. Mestranda, Biologia Microbiana, IB - UnB, Brasília, DF, Brasil; 5. \\ Professor, Fitopatologia, IB - UnB, Brasília, DF, Brasil; 6. Bolsista de Produtividade do CNPq, Professor, Fitopatologia, IB - UnB, \\ Brasília, DF, Brasil. luizblum@unb.br
}

\begin{abstract}
This work was carried out to select and to evaluate efficacy of Trichoderma isolates to control sclerotium wilt (Sclerotium rolfsii) of common-bean (Phaseolus vulgaris). For the experiments were used two isolates of S. rolfsii UB 193 and UB 228. Sixty-five Trichoderma spp. isolates were tested and the following ones were selected in vitro for the in vivo tests: 5, 11, 12, 15, 102, 103, 127, 136, 137, 1525 (T. longibrachiatum), 1637 (T. reesei), 1642, 1643 (T. harzianum), 1649 (T. harzianum), 1700 (T. asperellum) and EST 5. The most promising isolates were identified by Sequencing of the internal transcribed spacer regions ITS1, ITS2, and the 5.8s rRNA genomic region, using the ITS5 and ITS4 primers and compared with sequences in the National Center for Biotechnology Information (NCBI) database. These selected isolates 1649 (T. harzianum), 1525 (T. longibrachiatum) and 1637 (T. reesei) were tested for evaluation of sclerotial germination inhibition under laboratory conditions, and to evaluate the effects of these on disease of bean plants under greenhouse conditions. The Trichoderma isolates 1649,1525 and 1637 were more efficient in reducing sclerotial germination. In addition to 1649,1525 and 1637, the isolates 5, 12, 102 and 1525 (T. longibrachiatum) significantly reduced de amount of diseased bean plants under greenhouse conditions.
\end{abstract}

KEYWORDS: Aethelia rolfsii. Phaseolus vulgaris. Biocontrol. Trichoderma spp.

\section{INTRODUCTION}

Sclerotium rolfsii Sacc. [Teleomorph: Athelia rolfsii (Cruzi) You \& Kimbrough] is a pathogen of widespread distribution in soils of agricultural production areas. This basidiomycetes fungus causes a disease (Southern-blight; dampingoff; sclerotium-wilt) that affects more than 500 species in over 100 plant families. This disease can be a serious problem, especially in warm regions, where the pathogen produces sclerotia in infected plant parts near the ground. The sclerotia can survive in the soil for a few months to several years, depending on environmental conditions (PUNJA, 1993; XU et al., 2008). These structures are the primary inoculum source for the development of the disease (PUNJA, 1993; XU et al., 2008). After germination of sclerotium, hyphae of $S$. rolfsii might produce oxalic acid, pectinolytic and cellulolytic enzymes that could disintegrate plant tissues (LE, 2011; PUNJA, 1993).

The control of $S$. rolfsii occurs with the aid of preventive practices such as crop rotation, deep plowing, fungicide-treated and pathogen-free seed, among others and by biological control (BLUM; LIN, 1991; SOUSA; BLUM, 2013), cultural control
(BLUM; RODRIGUÉZ-KÁBANA, 2004; BLUM; RODRIGUÉZ-KÁBANA, 2006; PINHEIRO et al., 2010), and chemical control (PAULA Jr. et al., 2011; SOUSA; BLUM, 2013). Biological control of plant pathogens has a number of advantages compared to conventional fungicides. While the fungicides feature only a temporary effect and require repeated applications during the growing period of culture, biological control agents are able to establish themselves, colonize and reproduce in the ecosystem (AVILA et al, 2005; AULER et al., 2013; MELO; FAULL, 2000).

Trichoderma is well documented as effective biological control agents of plant diseases (SOUSA; BLUM, 2013). The biological control of the pathogen on bean plants by using Trichoderma spp. and in combination with other techniques had been investigated (SOUSA; BLUM, 2013). The genus Trichoderma comprises a large number of species some of which act as biological control agents through one or more mechanisms (SHARMA, 2012).

Gajera et al. (2013) reported that Trichoderma spp. act as bio-control agents against fungal plant pathogens either indirectly or directly. Indirect mechanism comprises competition for 
nutrients and space, modification of the environmental conditions, antibiosis and induction of plant defensive mechanisms, however direct mechanism encompasses hyper-parasitism. The studies of hyper-parasitism also have demonstrated that Trichoderma produce a rich mixture of antifungal enzymes, including chitinases and $\beta-1,3$ glucanases. These enzymes are synergistic with each other, with other antifungal enzymes, and with other metabolites. These indirect and direct mechanisms may act coordinately and their importance in the bio-control process depends on the Trichoderma species and strain, the antagonized fungus, the crop plant, and the environmental conditions including nutrient availability, $\mathrm{pH}$, temperature and iron concentration (GAJERA et al., 2013).

Trichoderma spp. have been successfully used for management of diseases caused by Rhizoctonia solani in bean and tomato and by $S$. rolfsii in bean, cucumber, tomato, peanut, sugarbeet and soybean (BLUM; RODRIGUÉZ-KÁBANA, 2006; KOTASTHANE et al., 2015; NAEIMI et al, 2010). Trichoderma are multifunctional plant symbionts responsible for enhanced nutrient uptake, increased root and shoot growth, improved plant vigor and biotic or abiotic stress tolerance (HARMAN et al. 2008; HARMAN, 2011). Trichoderma asperellum, T. harzianum, $T$. longibrachiatum and $T$. reesei are among the species with promising strains for biocontrol purposes (MAYMON et al., 2004; BŁASZCZYK et al., 2014).

Due to this diversity of modes of action of Trichoderma spp. the constant search for new effective strains against plant pathogens is necessary. Therefore, the objective of the study was to evaluate isolates of Trichoderma spp. in vivo and in vitro, and, to compare in vitro selected Trichoderma spp. to in vivo control of sclerotiumwilt of common-bean.

\section{MATERIAL AND METHODS}

The present study was conducted at the laboratory of Mycology of the Department of Plant Pathology and at the Experimental Station of Biology of the 'Universidade de Brasília' (University of Brasília - UnB), Brasília/DF. The isolates of Sclerotium rolfsii (UB 193 and UB 228) and Trichoderma were obtained from the Mycological collection at the same University. Sclerotium rolfsii (UB 193 and UB 228) and Trichoderma spp. (Table 1) were maintained and sub-cultured $\left(25^{\circ} \mathrm{C} ; 12 \mathrm{~h}\right.$ light $)$ routinely on potato dextrose agar (PDA). Sclerotia of $S$. rolfsii for in vitro tests were produced on PDA after 2 weeks $\left(25^{\circ} \mathrm{C} ; 12 \mathrm{~h}\right.$ light $)$.

Table 1. Isolates of Trichoderma spp. used in experiments.

\begin{tabular}{|c|c|}
\hline Trichoderma & Identification code* \\
\hline T. asperellum & $\begin{array}{l}1574 \text { (KT001987), } 1575 \text { (KC859427), } 1577 \text { (KP340248), 1581 (KF737411), } \\
1700 \text { (LC057426) }\end{array}$ \\
\hline T. aureoviride & 1638 \\
\hline T. harzianum & $\begin{array}{l}1643 \text { (KP263734), } 1645 \text { (KP263580), } 1646 \text { (KP263734), } 1647 \text { (KP263642), } \\
1649 \text { (KP418577), } 1650 \text { (KP263580) }\end{array}$ \\
\hline T. koningii & 1578,1743 \\
\hline T. longibrachiatum & $\begin{array}{l}112 \text { (KP671488), } 245 \text { (KM457631), } 1168 \text { (KC009811), } 1169 \text { (EU401554), } 1523 \\
\text { (KP641159), } 1525 \text { (GQ203533), } 1526 \text { (KJ767090), } 1576 \text { (KP256797), } 1641 \\
\text { (KM225906), } 1644 \text { (KP009307), } 1742 \text { (KP671488), } 1744 \text { (KC582841) }\end{array}$ \\
\hline T. pilluliferum & 1640 \\
\hline T. reesei & $1168,1637(\mathrm{LC} 002607)$ \\
\hline T. viride & $1639(\mathrm{FN} 868471)$ \\
\hline Trichoderma sp. & $\begin{array}{l}5,7,8,9,11,12,13,15,23,24,25,102,103,104,109,113,116,118,122,123, \\
127,131,132,136,137,518,1330,1528,1529,1642 \text {, Est02, Est05, Est06, } \\
\text { Est07, SG, UFG }\end{array}$ \\
\hline
\end{tabular}

Total DNA was extracted from Trichoderma isolates (Table 1) analyzed samples, following the cetyltrimethyl ammonium bromide (CTAB) method (DOYLE; DOYLE, 1990). All isolates of Trichoderma asperellum, T. harzianum, and T. longibrachiatum and some the other
Trichoderma spp. were identified by sequencing of the internal transcribed spacer regions ITS1, ITS2, and the 5.8s rRNA genomic region, using the ITS5 (5'-GGAAGTAAAAGTCGTAACAAGG-3') and ITS4 (5'-TCCTCCGCTTATTGATATGC-3') primers (WHITE et al., 1990); and compared with 
sequences in the National Center for Biotechnology Information (NCBI) database (http://www.ncbi.nlm.nih.gov). PCR products were treated with ExoSAP-IT enzyme and then sequenced with an 'ABI 3130xl da Applied Biosystems' sequencer at the 'Universidade Católica de Brasília' (Catholic University of Brasilia - UCB). The alignments were constructed with MEGA Version 6 (http://megasoftware.net/) and only the ones with more than $95 \%$ of identity were considered for phylogenetic purposes. Statistical significance was evaluated with a bootstrapping of 1000 repetitions (TAMURA et al., 2013).

The tests for evaluation of the in vitro antagonism of 65 Trichoderma spp. isolates (Table 1) against $S$. rolfsii were performed using the method of paired cultures described by Dennis e Webster (1971). Plates of PDA were inoculated with a $5 \mathrm{~mm}$ disc of $S$. rolfsii $10 \mathrm{~mm}$ from the edge of the plate. A $5 \mathrm{~mm}$ disc of the tested Trichoderma isolate was placed $60 \mathrm{~mm}$ from the $S$. rolfsii disc. As experimental control were used Petri dishes with BDA containing only culture isolates of $S$. rolfsii. The evaluations were carried out on the seventh day of incubation $\left(25^{\circ} \mathrm{C} ; 12 \mathrm{~h}\right.$ light $)$, using a scale of scores according to the method of Bell et al. (1982). The mycelial interaction between pathogen and antagonist was scored from 1 to 5 according to Bell et al. (1982). This scale of classes designated by Bell et al. (1982) is the following: (1) Trichoderma completely overgrew $S$. rolfsii, occupying the whole 9-cm Petri-dish; (2) Trichoderma occupies at least
65\% of the Petri dish; (3) Trichoderma and S. rolfsii grow around (40-60\%) of the Petri dish; (4) Sclerotium rolfsii occupies at least $65 \%$ of the Petri dish without any apparent interference of Trichoderma; (5) Sclerotium rolfsii completely overgrew Trichoderma, occupying the whole Petri dish. A complete randomized design with 66 treatments and 4 replications was used, and after analysis of variance ( $\mathrm{F}$ test; $\mathrm{P} \leq 0.05)$, treatments averages were compared through the Scott-Knott test $(\mathrm{P} \leq 0.05)$.

The effects of 15 in vitro selected Trichoderma spp. (Table 2) on germination of $S$. rolfsii sclerotia were evaluated by using plastic boxes (Gerbox type plastic box - $11.5 \times 3.5 \mathrm{~cm}$ ) with sterilized $\left(121{ }^{\circ} \mathrm{C} ; 1 \mathrm{~h}\right)$ soil. The plastic boxes received $200 \mathrm{~g}$ of wet $(70 \mathrm{~mL}$ of sterile water), sieved and sterilized soil [Red latosol (Oxisol); $\mathrm{pH}$ $\left.\left(\mathrm{H}_{2} \mathrm{O}\right)=5.5 ; \mathrm{OM}=8.6 \mathrm{~g} / \mathrm{kg}\right]$. Four replications of 25 sclerotia / plastic box were inoculated with $20 \mu \mathrm{l}$ of Trichoderma ( $1 \times 10^{7}$ conidia / $\left.\mathrm{mL}\right)$ isolates suspension / sclerotium. Sterile water $(20 \mu \mathrm{l})$ was applied on a set of sclerotia as experimental control. After the application of treatments, the inoculated containers were settled in an incubator $\left(25^{\circ} \mathrm{C} ; 12 \mathrm{~h}\right.$ light). The evaluations occurred after 7 and 14 days of incubation, by counting the number of nongerminated sclerotia. A complete randomized design with 66 treatments and 4 replications was used, and after ANOVA ( $\mathrm{F}$ test; $\mathrm{P} \leq 0.05$ ), treatments averages were compared [Scott-Knott test $(\mathrm{P} \leq 0.05)]$.

Table 2. In vitro antagonism of Trichoderma (TR) against Sclerotium rolfsii (UB 193; 288), using scores (1-5) according to Bell et al. (1982), after 7 days of incubation $\left(25^{\circ} \mathrm{C} ; 12 \mathrm{~h}\right.$ light).

\begin{tabular}{ccccccccc}
\hline TR & UB 193 & UB 288 & TR & UB $\mathbf{1 9 3}$ & UB 288 & TR & UB $\mathbf{1 9 3}$ & UB 288 \\
\hline Test & $5.0{ }^{(1)} \mathrm{a}$ & $5.0 \mathrm{a}$ & $\mathbf{U F G}$ & $3.0 \mathrm{c}$ & $3.3 \mathrm{c}$ & $\mathbf{1 5 8 1}$ & $2.3 \mathrm{~d}$ & $3.0 \mathrm{c}$ \\
$\mathbf{5 1 8}$ & $4.5 \mathrm{~b}^{(2)}$ & $4.8 \mathrm{a}$ & $\mathbf{2 3}$ & $2.8 \mathrm{c}$ & $3.3 \mathrm{c}$ & $\mathbf{5}$ & $2.0 \mathrm{~d}$ & $2.0 \mathrm{~d}$ \\
$\mathbf{1 6 4 0}$ & $4.3 \mathrm{~b}$ & $5.0 \mathrm{a}$ & $\mathbf{1 0 4}$ & $2.8 \mathrm{c}$ & $4.3 \mathrm{~b}$ & $\mathbf{9}$ & $2.0 \mathrm{~d}$ & $3.5 \mathrm{c}$ \\
$\mathbf{1 0 9}$ & $4.0 \mathrm{~b}$ & $5.0 \mathrm{a}$ & $\mathbf{1 1 3}$ & $2.8 \mathrm{c}$ & $3.0 \mathrm{c}$ & $\mathbf{2 4}$ & $2.0 \mathrm{~d}$ & $3.0 \mathrm{c}$ \\
$\mathbf{1 3}$ & $3.5 \mathrm{c}$ & $3.0 \mathrm{c}$ & $\mathbf{1 1 6}$ & $2.8 \mathrm{c}$ & $3.0 \mathrm{c}$ & $\mathbf{2 5}$ & $2.0 \mathrm{~d}$ & $3.0 \mathrm{c}$ \\
$\mathbf{1 1 8}$ & $3.3 \mathrm{c}$ & $3.8 \mathrm{~b}$ & $\mathbf{1 3 1}$ & $2.8 \mathrm{c}$ & $2.8 \mathrm{c}$ & $\mathbf{1 0 2}$ & $2.0 \mathrm{~d}$ & $2.0 \mathrm{~d}$ \\
$\mathbf{1 3 3 0}$ & $3.3 \mathrm{c}$ & $3.8 \mathrm{~b}$ & $\mathbf{2 4 5}$ & $2.8 \mathrm{c}$ & $3.0 \mathrm{c}$ & $\mathbf{1 0 3}$ & $2.0 \mathrm{~d}$ & $2.5 \mathrm{~d}$ \\
$\mathbf{1 5 2 3}$ & $3.3 \mathrm{c}$ & $4.0 \mathrm{~b}$ & $\mathbf{1 1 6 9}$ & $2.8 \mathrm{c}$ & $2.5 \mathrm{~d}$ & $\mathbf{1 2 2}$ & $2.0 \mathrm{~d}$ & $2.8 \mathrm{c}$ \\
$\mathbf{1 5 2 9}$ & $3.3 \mathrm{c}$ & $3.0 \mathrm{c}$ & $\mathbf{1 5 2 6}$ & $2.8 \mathrm{c}$ & $3.0 \mathrm{c}$ & $\mathbf{1 2 7}$ & $2.0 \mathrm{~d}$ & $2.5 \mathrm{~d}$ \\
$\mathbf{1 6 4 7}$ & $3.3 \mathrm{c}$ & $4.0 \mathrm{~b}$ & $\mathbf{1 5 7 7}$ & $2.8 \mathrm{c}$ & $2.8 \mathrm{c}$ & $\mathbf{1 3 2}$ & $2.0 \mathrm{~d}$ & $3.0 \mathrm{c}$ \\
$\mathbf{1 7 4 2}$ & $3.3 \mathrm{c}$ & $3.3 \mathrm{c}$ & $\mathbf{1 6 4 4}$ & $2.8 \mathrm{c}$ & $3.3 \mathrm{c}$ & $\mathbf{1 3 6}$ & $2.0 \mathrm{~d}$ & $2.3 \mathrm{~d}$ \\
$\mathbf{1 7 4 3}$ & $3.3 \mathrm{c}$ & $2.8 \mathrm{c}$ & $\mathbf{1 6 5 0}$ & $2.8 \mathrm{c}$ & $2.3 \mathrm{~d}$ & $\mathbf{1 3 7}$ & $2.0 \mathrm{~d}$ & $2.0 \mathrm{~d}$ \\
$\mathbf{7}$ & $3.0 \mathrm{c}$ & $2.8 \mathrm{c}$ & $\mathbf{1 7 4 4}$ & $2.8 \mathrm{c}$ & $2.8 \mathrm{c}$ & $\mathbf{1 5 2 5}$ & $2.0 \mathrm{~d}$ & $2.3 \mathrm{~d}$ \\
$\mathbf{1 1 2}$ & $3.0 \mathrm{c}$ & $3.0 \mathrm{c}$ & $\mathbf{E s t ~ 0 2}$ & $2.8 \mathrm{c}$ & $2.3 \mathrm{~d}$ & $\mathbf{1 6 3 7}$ & $2.0 \mathrm{~d}$ & $2.5 \mathrm{~d}$ \\
$\mathbf{1 1 6 8}$ & $3.0 \mathrm{c}$ & $3.0 \mathrm{c}$ & $\mathbf{8}$ & $2.5 \mathrm{~d}$ & $3.3 \mathrm{c}$ & $\mathbf{1 6 4 3}$ & $2.0 \mathrm{~d}$ & $2.5 \mathrm{~d}$ \\
$\mathbf{1 5 7 5}$ & $3.0 \mathrm{c}$ & $3.0 \mathrm{c}$ & $\mathbf{1 2 3}$ & $2.5 \mathrm{~d}$ & $3.0 \mathrm{c}$ & $\mathbf{1 7 0 0}$ & $2.0 \mathrm{~d}$ & $2.3 \mathrm{~d}$
\end{tabular}




\begin{tabular}{ccccccccc}
$\mathbf{1 5 7 6}$ & $3.0 \mathrm{c}$ & $3.5 \mathrm{c}$ & $\mathbf{1 6 3 8}$ & $2.5 \mathrm{~d}$ & $2.8 \mathrm{c}$ & $\mathbf{E s t ~ 0 5}$ & $2.0 \mathrm{~d}$ & $2.0 \mathrm{~d}$ \\
$\mathbf{1 5 7 8}$ & $3.0 \mathrm{c}$ & $3.0 \mathrm{c}$ & $\mathbf{1 6 4 1}$ & $2.5 \mathrm{~d}$ & $3.0 \mathrm{c}$ & $\mathbf{1 2}$ & $1.8 \mathrm{e}$ & $2.5 \mathrm{~d}$ \\
$\mathbf{1 6 3 9}$ & $3.0 \mathrm{c}$ & $3.3 \mathrm{c}$ & $\mathbf{1 6 4 6}$ & $2.5 \mathrm{~d}$ & $3.0 \mathrm{c}$ & $\mathbf{1 6 4 2}$ & $1.8 \mathrm{e}$ & $1.8 \mathrm{~d}$ \\
Est 06 & $3.0 \mathrm{c}$ & $3.0 \mathrm{c}$ & $\mathbf{1 1}$ & $2.3 \mathrm{~d}$ & $2.0 \mathrm{~d}$ & $\mathbf{1 6 4 5}$ & $1.5 \mathrm{e}$ & $5.0 \mathrm{a}$ \\
Est 07 & $3.0 \mathrm{c}$ & $2.8 \mathrm{c}$ & $\mathbf{1 5 2 8}$ & $2.3 \mathrm{~d}$ & $3.0 \mathrm{c}$ & $\mathbf{1 6 4 9}$ & $1.5 \mathrm{e}$ & $2.0 \mathrm{~d}$ \\
S. G & $3.0 \mathrm{c}$ & $3.00 \mathrm{c}$ & $\mathbf{1 5 7 4}$ & $2.3 \mathrm{~d}$ & $3.0 \mathrm{c}$ & $\mathbf{1 5}$ & $1.0 \mathrm{e}$ & $1.8 \mathrm{~d}$ \\
\hline- & - & - & - & - & - & $\mathbf{C V}^{(3)}$ & 15,6 & 14,2 \\
\hline
\end{tabular}

(1) Average of four Petri-dishes cultures as replications. Scale of classes (Bell et al., 1982): 1- Trichoderma completely overgrew the pathogen, occupying the whole petri dish; 2- Trichoderma occupies at least $65 \%$ of the medium plate; 3- Trichoderma and pathogen grow around (40-60\%) of the Petri dish; 4- Pathogen occupies at least $65 \%$ of the Petri dish without any apparent interference of Trichoderma; 5- Pathogen completely overgrew Trichoderma, occupying the whole Petri dish. (2) Values in column followed by the same letter are not significantly different according to the Scott-Knott test $(\mathrm{P} \leq 5 \%)$. (3) Coefficient of variation $(\%)$.

Greenhouse $\left(20-30^{\circ} \mathrm{C}\right)$ tests were conducted at the Experimental Station of Biology of the University of Brasilia. Seeds of bean cv. 'Pérola' were sowed in $3 \mathrm{~L}$ black plastic pots with a capacity of $3 \mathrm{~kg}$ of sterilized $\left(121^{\circ} \mathrm{C} ; 1 \mathrm{~h}\right)$ soil. For each treatment, five pots with 8 bean seeds were prepared. The soil [Red latosol (Oxisol); $\mathrm{pH} \mathrm{H}_{2} \mathrm{O}$, $5.5 ; \mathrm{P}=0.5 \mathrm{mg} / \mathrm{dm}^{3} ; \mathrm{Ca}=0.5 \mathrm{cmol} / \mathrm{dm}^{3} ; \mathrm{Mg}=0.4$ $\mathrm{cmol} / \mathrm{dm}^{3} ; \mathrm{K}=0.04 \mathrm{cmol} / \mathrm{dm}^{3} ; \mathrm{Na}=0.01 \mathrm{cmol} / \mathrm{dm}^{3}$; $\mathrm{Al}=0.1 \mathrm{cmol} / \mathrm{dm} 3 ; \mathrm{OM}=8.6 \mathrm{~g} / \mathrm{kg}$ ] was previously fertilized by adding and mixing N-P-K (4-14-8; $2.5 \mathrm{~g}$ / $\mathrm{kg}$ of soil). Once a day, by dripping, soil of each plastic pot received $0.5 \mathrm{~L}$ of water. A complete randomized block design with 15 treatments and 5 replications was used, and after ANOVA (F test; P $\leq$ $0.05)$, treatments averages were compared through the Scott-Knott test $(\mathrm{P} \leq 0.05)$.

To inoculated the soil for the greenhouse tests, the pathogens and antagonists were grown for 10 days $\left(25^{\circ} \mathrm{C} ; 12 \mathrm{~h}\right.$ light $)$ on sterilized $\left(120^{\circ} \mathrm{C} ; 20\right.$ minutes) water soaked rice grains using a modified (Auler at al., 2013) method described by Serra e Silva (2005). The soil inoculations were made following a modified method described by Barbosa et al. (2010), where, $10 \mathrm{~g} \mathrm{~kg}^{-1}$ of soil of pathogen or Trichoderma colonized rice seeds were mixed to the pot soil content. The evaluation of the number of diseased plants was made weekly up to 42 days after the soil inoculation. After this period, the dry matter of the roots and aerial plant parts was quantified. A Pearson correlation coefficient test was made between the percentage of non-germinated sclerotia (laboratory) and amount of diseased bean plants (greenhouse), considering de results of all Trichoderma isolates in both $S$. rolfsii (UB 193 and 228).

\section{RESULTS AND DISCUSSION}

Most of the Trichoderma isolates in vitro inhibited mycelial growth of $S$. rolfsii (UB 193; 228) isolates (Table 2). Five Trichoderma isolates
$(12,1642,1645,1649$, and 15) kept under 2, on Bell's et al. (1982) scale, the $S$. rolfsii (193) isolate. Trichoderma isolate (1645) inhibited one $S$. rolfsii (193) isolate but did not inhibit the other (228). Three Trichoderma isolates, 1642, 1649, and 15, reduced significantly the mycelial growth of $S$. rolfsii.

Castillo et al. (2011) reported the antagonism in vitro effect of Mexicans Trichoderma strains on Sclerotinia sclerotiorum and Sclerotium cepivorum. In addition, Paica (2014) found that a strain of $T$. asperellum was characterized as an in vitro antagonist of Fusarium and Aspergillus isolates from corn (Zea mays). The type of Trichoderma antagonism to plant pathogenic fungi varies. Some isolates of $T$. harzianum and T. asperellum were reported to act by antibiosis and parasitism on different fungal pathogens (AULER et al., 2013; CASTILLO et al., 2011; ISAIAS et al., 2014; MARTINEZ et al., 2013; PAICA, 2014; PARMAR et al., 2015). Rasu et al. (2012) indicated the potential of $T$. asperellum in inhibiting the mycelial growth of $S$. rolfsii and production of cell wall degrading enzyme. Sanmartín-Negredo et al. (2012) concluded that the antagonistic activity of $T$. asperellum against $C$. gloeosporioides is due mainly to the biocidal effect of volatile metabolites.

Those Trichoderma isolates which in vitro inhibited mycelial growth (Table 2) of $S$. rolfsii, three $(1637,1525,1694)$ of them were able of significantly to reduce sclerotial germination (Table 3 ). These three isolates were of $T$. reesei (1637), $T$. longibrachiatum (1525), and T. harzianum (1694). Trichoderma asperellum (1700) in vitro inhibited both $S$. rolfsii isolates, but only significantly reduced the sclerotial germination of one $S$. rolfsii isolate (UB 228). Henis et al. (1983) found that not only direct Trichoderma sclerotial penetration degrades sclerotium of $S$. rolfsii. These authors also indicated that enzymes and non-enzymatic toxins might be involved sclerotial germination and 
degradation. Additionally, Desai e Schlosser (1999) showed that their isolates of $T$. harzianum mainly acted by post-penetration parasitism of the $S$. rolfsii sclerotia.

The isolates 1525 of $T$. longibrachiatum, 1637 of $T$ reesei, 1649 of $T$. harzianum, 1700 of $T$. asperellum, 5, 11, 12, 15, Est 5, 102, 103, 127, and 137 of Trichoderma sp. significantly reduced the amount of diseased bean plants (Table 4). Trichoderma longibrachiatum (1525), T. harzianum (1649), and Trichoderma sp. $(102 ; 103)$ were the most efficient in reducing $S$. rolfsii (UB 193; UB
228) diseased bean plants. With the exception of Trichoderma sp. (103) all other previously cited isolates were efficient in reducing sclerotium germination (Table 3). The isolate 1643 of $\mathrm{T}$. harzianum reduced significantly $S$. rolfsii sclerotium germination (Table 3) but did not reduced disease on plants (Table 4). Considering all Trichoderma isolates (Tables 3 and 4) there was a significant negative correlation $(\mathrm{r}=-0,585 ; \mathrm{P}=0,017)$ between the percentage of non-germinated sclerotia and amount of diseased bean plants.

Table 3. Percentage of non-germinated (NG) sclerotia of Sclerotium rolfsii (UB 193; UB 228), 14 days after application of Trichoderma spp. (20 $\mathrm{\mu l} /$ sclerotium; 1 × $10^{7}$ conidia / $\left.\mathrm{mL}\right)$.

\begin{tabular}{llcc}
\hline Treatment & Trichoderma & UB $193\left[\% \mathbf{N G}^{(1)}\right]$ & UB 228 [\% NG] \\
\hline $\mathbf{1 6 4 9}$ & T. harzianum & $77 \mathrm{a}^{(2)}$ & $80 \mathrm{a}$ \\
$\mathbf{1 5 2 5}$ & T. longibrachiatum & $53 \mathrm{~b}$ & $73 \mathrm{a}$ \\
$\mathbf{1 6 4 3}$ & T. harzianum & $37 \mathrm{c}$ & $34 \mathrm{~b}$ \\
$\mathbf{1 0 2}$ & T. reesei & $33 \mathrm{c}$ & $66 \mathrm{a}$ \\
$\mathbf{1 3 7}$ & Trichoderma sp. & $33 \mathrm{c}$ & $64 \mathrm{a}$ \\
$\mathbf{5}$ & Trichoderma sp. & $32 \mathrm{c}$ & $39 \mathrm{~b}$ \\
Est $\mathbf{0 5}$ & Trichoderma sp. & $24 \mathrm{c}$ & $73 \mathrm{a}$ \\
$\mathbf{1 3 6}$ & Trichoderma sp. & $23 \mathrm{c}$ & $63 \mathrm{a}$ \\
$\mathbf{1 2}$ & Trichoderma sp. & $23 \mathrm{c}$ & $30 \mathrm{~b}$ \\
$\mathbf{1 5}$ & Trichoderma sp. & $22 \mathrm{c}$ & $70 \mathrm{a}$ \\
$\mathbf{1 7 0 0}$ & Trichoderma sp. & $19 \mathrm{~d}$ & $68 \mathrm{a}$ \\
$\mathbf{1 1}$ & T. asperellum & $19 \mathrm{~d}$ & $39 \mathrm{~b}$ \\
$\mathbf{1 2 7}$ & Trichoderma sp. & $14 \mathrm{~d}$ & $30 \mathrm{~b}$ \\
$\mathbf{1 0 3}$ & Trichoderma sp. & $14 \mathrm{~d}$ & $26 \mathrm{c}$ \\
None & Trichoderma sp. & $9 \mathrm{~d}$ & $33 \mathrm{~b}$ \\
\hline \multicolumn{1}{c}{ CV $(\boldsymbol{\%})$} & None & $0 \mathrm{~d}$ & $0 \mathrm{~d}$ \\
\hline
\end{tabular}

(1) Average of 4 replications of 25 sclerotia; (2) Values in column followed by the same letter are not significantly different according to the Scott-Knott test $(\mathrm{P} \leq 5 \%)$. (3) Coefficient of variation.

Auler at al. (2013) reported that the isolates CEN155, CEN158, CEN169, CEN170, CEN194 and CEN197 of Trichoderma harzianum were able to inhibit the mycelial growth of $S$. rolfsii and were effective for controlling $S$. rolfsii on bean and soybean crops, affording over $88 \%$ of healthy plants. Błaszczyk et al. (2014) informed that chitinases are the most important lytic enzymes playing a key role in the degradation of cell walls of other plant pathogenic fungi by Trichoderma species (T. harzianum, $T$. atroviride and $T$. asperellum).

El-Komy et al. (2015) showed that around of $20 \%$ of their T. asperellum isolates were highly producer for cell-wall degrading enzymes and showed high antagonistic activity against Fusarium oxysporum f. sp. lycopersici isolates. There was a positive correlation between the antagonistic capacity of $T$. asperellum isolates towards $F$. oxysporum f. sp. lycopersici and their lytic enzyme production. Isolates showing high levels of chitinase and $\beta-1,3$-glucanase activities strongly inhibited the growth of $F$. oxysporum f. sp. lycopersici.

The isolate 1649 of T. harzianum was very efficient in inhibit $S$. rolfsii mycelia growth (Table 2 ), reduce sclerotial germination (table 3 ), reduce disease incidence (Table 4) and promote bean plant growth (Table 5). Trichoderma longibrachiatum (1525) also was efficient in inhibit $S$. rolfsii mycelia growth (Table 2), reduce sclerotial germination (Table 3), reduce disease incidence (Table 4) and promote bean plant growth (Table 5), but not as well 
as T. harzianum (1649). Pedro et al. (2012) reported a reduction on severity of bean anthracnose (Colletotrichum lindemuthianum) and promotion of plant growth by isolates of Trichoderma under greenhouse conditions. Martínez-Medina et al. (2014) found that changes in phytohormone levels is one of the mechanisms by which selected Trichoderma isolates can interfere with plant growth. In addition, these authors informed an important role of auxin in controlling plant growth stimulation by Trichoderma, while plant-mediated mechanisms by which Trichoderma can control Fusarium (Fusarium oxysporum f. sp. melonis) wilt of melon (Cucumis melo) may be influenced by shoot content of ZR, ABA, and ACC.

Table 4. Percentage of diseased bean (cv. Pérola) plants after 6 weeks of the application of Trichoderma spp. into soil previously contaminated with Sclerotium rolfsii (UB 193 or 228).

\begin{tabular}{|c|c|c|c|c|}
\hline \multirow{3}{*}{ TRATAMENT } & \multirow{3}{*}{ Trichoderma } & \multicolumn{3}{|c|}{$\%$ of diseased plants } \\
\hline & & \multicolumn{2}{|c|}{ S. rolfsii } & \multirow[b]{2}{*}{ Average } \\
\hline & & UB 193 & UB 228 & \\
\hline S. rolfsii & - & $97^{(1)} \mathrm{aA}^{(2)}$ & $98 \mathrm{a}^{(3)} \mathrm{A}$ & $97 \mathrm{~A}$ \\
\hline S. rolfsii +1643 & T. harzianum & $92 \mathrm{aA}$ & $86 \mathrm{aB}$ & $89 \mathrm{~B}$ \\
\hline S. rolfsii +15 & Trichoderma sp. & $69 \mathrm{bB}$ & $83 \mathrm{aB}$ & $76 \mathrm{C}$ \\
\hline S. rolfsii +11 & Trichoderma sp. & $58 \mathrm{bC}$ & $68 \mathrm{aC}$ & $64 \mathrm{D}$ \\
\hline S. rolfsii +1700 & T. asperellum & $47 \mathrm{bD}$ & $66 \mathrm{aC}$ & $57 \mathrm{E}$ \\
\hline S. rolfsii + Est 5 & Trichoderma sp. & $53 \mathrm{aC}$ & $56 \mathrm{aD}$ & $55 \mathrm{E}$ \\
\hline S. rolfsii +1637 & T. reesei & $47 \mathrm{bD}$ & $63 \mathrm{aD}$ & $55 \mathrm{E}$ \\
\hline S. rolfsii + 127 & Trichoderma sp. & $40 \mathrm{bE}$ & $68 \mathrm{aC}$ & $54 \mathrm{E}$ \\
\hline S. rolfsii +137 & Trichoderma sp. & $63 \mathrm{aB}$ & $44 \mathrm{bE}$ & $54 \mathrm{E}$ \\
\hline S. rolfsii +136 & Trichoderma sp. & $57 \mathrm{aC}$ & $46 \mathrm{bE}$ & $51 \mathrm{E}$ \\
\hline S. rolfsii +5 & Trichoderma sp. & $38 \mathrm{aE}$ & $42 \mathrm{aE}$ & $40 \mathrm{~F}$ \\
\hline S. rolfsii +12 & Trichoderma sp. & $48 \mathrm{aD}$ & $17 \mathrm{bG}$ & $32 \mathrm{G}$ \\
\hline S. rolfsii +1525 & T. longibrachiatum & $29 \mathrm{aF}$ & $32 \mathrm{aF}$ & $31 \mathrm{G}$ \\
\hline S. rolfsii + 103 & Trichoderma sp. & $27 \mathrm{aF}$ & $18 \mathrm{bG}$ & $22 \mathrm{H}$ \\
\hline S. rolfsii +1649 & T. harzianum & $30 \mathrm{aF}$ & $9 \mathrm{bH}$ & $19 \mathrm{H}$ \\
\hline S. rolfsii + 102 & Trichoderma sp. & $21 \mathrm{aG}$ & $6 \mathrm{bH}$ & $14 \mathrm{I}$ \\
\hline No $S$. rolfsii & - & $0 \mathrm{aH}^{(2)}$ & $0 \mathrm{aI}$ & $0 \mathrm{~J}$ \\
\hline $\mathrm{CV}^{(4)}$ & - & - & - & 12 \\
\hline
\end{tabular}

(1) Average of 5 replications of 8 plants; ${ }^{(2)}$ Values in column followed by the same capital letter are not significantly different according to Scott-Knott test $(\mathrm{P} \leq 5 \%)$. ${ }^{(3)}$ Values in row followed by the same low-case letter are not significantly different according to ScottKnott test $(\mathrm{P} \leq 5 \%)$. ${ }^{(4)}$ Coefficient of variation; original data were transformed to arcsin $\{$ sqrt $[(\mathrm{x}+0.5) / 100]\}$, where $\mathrm{x}$ is the $\%$.

Table 5. Shoot and root fresh mass (g) of bean (cv. 'Pérola) plants grown in soil contaminated with Sclerotium rolfsii and Trichoderma spp., under greenhouse conditions.

\begin{tabular}{llcccc}
\hline \multirow{2}{*}{ TRATAMENT } & \multirow{2}{*}{ Trichoderma } & \multicolumn{2}{c}{ S. rolfsii UB 193 } & \multicolumn{2}{c}{ S. rolfsii UB 228 } \\
\cline { 3 - 6 } & & Shoot & Root & Shoot & Root \\
\hline None ${ }^{(1)}$ & - & $51.7 \mathrm{a}(2)$ & $4.6 \mathrm{a}$ & $44.0 \mathrm{a}$ & $3.1 \mathrm{c}$ \\
$\mathbf{1 6 4 9}$ & T. harzianum & $44.4 \mathrm{a}$ & $2.7 \mathrm{~b}$ & $47.8 \mathrm{a}$ & $3.6 \mathrm{c}$ \\
$\mathbf{1 0 2}$ & Trichoderma sp. & $20.0 \mathrm{~b}$ & $3.9 \mathrm{a}$ & $13.7 \mathrm{c}$ & $1.9 \mathrm{~d}$ \\
$\mathbf{5}$ & Trichoderma sp. & $27.3 \mathrm{~b}$ & $3.2 \mathrm{a}$ & $27.9 \mathrm{~b}$ & $3.3 \mathrm{c}$ \\
$\mathbf{1 0 3}$ & Trichoderma sp. & $33.6 \mathrm{~b}$ & $6.1 \mathrm{a}$ & $34.6 \mathrm{~b}$ & $8.2 \mathrm{~b}$ \\
$\mathbf{1 2 7}$ & Trichoderma sp. & $29.2 \mathrm{~b}$ & $5.9 \mathrm{a}$ & $32.1 \mathrm{~b}$ & $7.4 \mathrm{~b}$ \\
$\mathbf{1 2}$ & Trichoderma sp. & $21.9 \mathrm{~b}$ & $2.4 \mathrm{~b}$ & $19.9 \mathrm{c}$ & $1.4 \mathrm{~d}$ \\
$\mathbf{1 3 6}$ & Trichoderma sp. & $25.1 \mathrm{~b}$ & $3.6 \mathrm{a}$ & $30.2 \mathrm{~b}$ & $4.5 \mathrm{c}$ \\
$\mathbf{1 3 7}$ & Trichoderma $\mathbf{s p}$ & $25.7 \mathrm{~b}$ & $1.8 \mathrm{~b}$ & $34.2 \mathrm{~b}$ & $2.7 \mathrm{c}$ \\
$\mathbf{1 6 3 7}$ & T. reesei & $26.6 \mathrm{~b}$ & $3.7 \mathrm{a}$ & $22.8 \mathrm{c}$ & $1.7 \mathrm{~d}$
\end{tabular}




\begin{tabular}{|c|c|c|c|c|c|}
\hline 1700 & T. asperellum & $25.4 \mathrm{~b}$ & $3.0 \mathrm{a}$ & $18.9 \mathrm{c}$ & $1.9 \mathrm{~d}$ \\
\hline 11 & Trichoderma sp. & $27.2 \mathrm{~b}$ & $3.3 \mathrm{a}$ & $21.6 \mathrm{c}$ & $1.8 \mathrm{~d}$ \\
\hline 1525 & T. longibrachiatum & $21.0 \mathrm{~b}$ & $4.7 \mathrm{a}$ & $27.8 \mathrm{~b}$ & $4.6 \mathrm{c}$ \\
\hline EST 5 & Trichoderma sp. & $24.1 \mathrm{~b}$ & $4.1 \mathrm{a}$ & $23.9 \mathrm{c}$ & $2.6 \mathrm{c}$ \\
\hline 15 & Trichoderma sp. & $29.5 \mathrm{~b}$ & $4.9 \mathrm{a}$ & $35.7 \mathrm{~b}$ & $11.1 \mathrm{a}$ \\
\hline 1643 & T. harzianum & $7.6 \mathrm{c}$ & $0.5 \mathrm{c}$ & $15.4 \mathrm{c}$ & $0.7 \mathrm{~d}$ \\
\hline S. rolfsii ${ }^{(3)}$ & - & $0,00 \mathrm{c}$ & $0,00 \mathrm{c}$ & $0,00 \mathrm{~d}$ & $0,00 \mathrm{~d}$ \\
\hline $\mathrm{CV}^{(4)}$ & & 19.2 & 27.2 & 13.9 & 22.0 \\
\hline
\end{tabular}

\section{CONCLUSIONS}

The Trichoderma isolates 1649, 1525 and 1637 were more efficient in reducing sclerotial germination. In addition to 1649,1525 and 1637 , the isolates 5, 12, 102 and 1525 ( $T$. longibrachiatum) significantly reduced de amount of diseased bean plants under greenhouse conditions.

The isolates 1649 of T. harzianum and 1525 of $T$. longibrachiatum were efficient in inhibit $S$. rolfsii mycelia growth, reduce sclerotial germination, reduce disease incidence and promote bean plant growth.

\section{ACKNOWLEDGMENTS}

The authors thank the National Council of Scientific and Technological Development (CNPq Brazil) and to the Coordination for the Improvement of Higher Education Personnel (CAPES - Brazil).

RESUMO: O estudo teve como objetivo selecionar e testar isolados de Trichoderma spp. para o controle da murcha-por-esclerócio (Sclerotium rolfsii) em feijoeiro (Phaseolus vulgaris) em casa-de-vegetação. Nos ensaios realizados foram utilizados dois isolados de S. rolfsii (UB 193 e UB 228). Dos 65 isolados Trichoderma testados in vitro selecionaram-se os seguintes: 5, 11, 12, 15, 102, 103, 127, 136, 137, 1525 (T. longibrachiatum), 1637 (T. reesei), 1642 (T. longibrachiatum), 1643 (T. harzianum), 1649 (T. harzianum), 1700 (T. asperellum) e EST 5. Os isolados mais promissores foram identificados por sequenciamento das regiões genômicas ITS1, ITS2 e 5.8s rRNA, usando iniciadores ITS5 e ITS4, e então, tais sequencias foram comparadas com as sequências do banco de dados do "National Center for Biotechnology Information" (NCBI). Esses isolados foram avaliados quanto ao efeito sobre a germinação de esclerócios do patógeno em laboratório e sobre a doença em casa de vegetação. Os isolados 1649 (T. harzianum), 1525 (T. longibrachiatum) e 1637 (T. reesei) foram os mais eficientes na inibição da germinação de esclerócios de $S$. rolfsii em laboratório. Além dos isolado 1649, 1525 e 1637, os isolados 5, 12, 102 e 1525 (T. longibrachiatum) foram eficientes na redução da doença em plantas de feijoeiro em casa de vegetação.

PALAVRAS-CHAVE: Aethelia rolfsii. Phaseolus vulgaris. Biocontrole. Trichoderma spp.

\section{REFERENCES}

AULER, A. C. V.; CARVALHO, D. D. C.; MELLO, S. C. M. Antagonismo de Trichoderma harzianum a Sclerotium rolfsii nas culturas do feijoeiro e soja. Revista agro@mbiente on-line, [S.1.], v. 7, n. 3, p. 359-365, dez. 2013.

ÁVILA, Z. R.; CARVALHO, S. S.; BRAÚNA, L. M.; GOMES, D. M. P. A.; MELLO, S. C. M. Seleção de isolados de Trichoderma spp. antagônicos a Sclerotium rolfsii e Sclerotinia sclerotiorum. Brasília: Embrapa Recursos Genéticos e Biotecnologia, Boletim de pesquisa e desenvolvimento, 117. 2005. 30 p.

BARBOSA, R. N. T.; HALFELD-VIEIRA, B. A.; NECHET, K. L.; SOUZA, G. R. Método para inoculação de Sclerotium rolfsii em feijoeiro. Revista Agro@mbiente on-line, v. 4, n. 1, p. 49-52, 2010. 
BELL, D. K.; WELLS, H. D.; MARKHAM, C. R. In vitro antagonism of Trichoderma species against six fungal plant pathogens. Phytopathology, St. Paul, v. 72, n. 4, p. 379-382, 1982.

BŁASZCZYK, SIWULSKI, M.; SOBIERALSKI. K.; LISIECKA, J.; JĘDRYCZKA M. Trichoderma spp. application and prospects for use in organic farming and industry. Journal of Plant Protection Research, v. 54, n. 4, p. 309-317, 2014.

BLUM, L. E. B.; LIN, M. T. Potencial de Trichoderma e Pseudomonas fluorescente para o controle do tombamento de mudas de eucalipto causado por Cylindrocladium spp. Fitopatologia Brasileira, Brasília, v. 16, n. 1, p. 71- 74, 1991.

BLUM, L. E. B.; RODRÍGUEZ-KÁBANA, R. Powders of kudzu, velvetbean, and pine bark added to soil increase microbial population and reduce southern blight of soybean. Fitopatologia Brasileira, Brasília, v. 31, n. 6, p. 551-556, 2006. http://dx.doi.org/10.1590/S0100-41582006000600003

BLUM, L. E. B.; RODRIGUEZ-KABANA, R. Effect of organic amendments on sclerotial germination, mycelial growth, and Sclerotium rolfsii-induced diseases. Fitopatologia Brasileira, v. 29, n. 1, p. 66-74, 2004. http://dx.doi.org/10.1590/S0100-41582004000100010

CASTILLO, F. D. H.; PADILLA, A. M. B.; MORALES, G. G.; SILLER, M. C.; HERRERA, R. R. In vitro antagonist action of Trichoderma strains against Sclerotinia sclerotiorum and Sclerotium cepivorum. American Journal of Agricultural and Biological Sciences., v. 6, p. 410-417, 2011. http://dx.doi.org/10.3844/ajabssp.2011.410.417

DENNIS, C.; WEBSTER, J. Antagonistic properties of species-groups of Trichoderma, III Hyphal interactions. Transactions British Mycological Society, Cambridge, v. 57, p. 363-369, 1971.

DESAI, S.; SCHLOSSER, E. Parasitism of Sclerotium rolfsii by Trichoderma. Indian Phytopathology, v. 52 , p. 47-50, 1999.

DOYLE, J. J.; DOYLE, J. L. Isolation of plant DNA from fresh tissue. Focus, v. 12, p. 13-15, 1990.

EL KOMY, M. H.; SALEH, A. A.; ERANTHODI, A.; MOLAN, Y. Y. Characterization of novel Trichoderma asperellum isolates to select effective biocontrol agents against tomato fusarium wilt. The Plant Pathology Journal, v. 31, n. 1, p. 50-60, 2015. http://dx.doi.org/10.5423/PPJ.OA.09.2014.0087

GAJERA, H.; DOMADIYA, R.; PATEL, S.; KAPOPARA, M.; GOLAKIYA, B. Molecular mechanism of Trichoderma as bio-control agents against phytopathogen system - a review. Current research in Microbiology and Biotechnology, v. 1, n. 4, p. 133-142, 2013.

HARMAN, G. E. Multifunctional fungal plant symbionts: new tools to enhance plant growth and productivity. New Phytologist, v. 189, p. 647-649, 2011. http://dx.doi.org/10.1111/j.1469-8137.2010.03614.x

HARMAN, G. E., BJORKMAN, T., ONDIK, K.; SHORESH, M. Changing paradigms on the mode of action and uses of Trichoderma spp. for biocontrol. Outlooks on Pest Management, v. 19, p. 24-29. 2008. http://dx.doi.org/10.1564/19feb08

HENIS, Y.; ADAMS, P. B.; LEWIS, J. A.; PAPAVIZAS, G. C. Penetration of sclerotia of Sclerotium rolfsii by Trichoderma spp. Phytopathology, v. 73, p. 1043-1046, 1983. http://dx.doi.org/10.1094/Phyto-731043

ISAIAS, C. O.; MARTINS, I.; SILVA, J. B. T.; SILVA, J. P.; MELLO, S. C. M. Ação antagônica e de metabólitos bioativos de Trichoderma spp. contra os patógenos Sclerotium rolfsii e Verticillium dahliae. Summa phytopathologica., v. 40, n. 1, p. 34-41. 2014. http://dx.doi.org/10.1590/S0100-54052014000100005 
KOTASTHANE, A.; AGRAWAL, T.; KUSHWAH, R.; RAHATKAR, V. In-vitro antagonism of Trichoderma spp. against Sclerotium rolfsii and Rhizoctonia solani and their response towards growth of cucumber, bottle gourd and bitter gourd. European Journal of Plant Pathology, v. 141, n. 3 p. 523-543, 2015. http://dx.doi.org/10.1007/s10658-014-0560-0

LE, C. N. Diversity and biological control of Sclerotium rolfsii, causal agent of stem rot of groundnut. Dissertation for the degree of doctor at Wageningen University, 152p. 2011.

MARTINEZ, B; INFANTE, D.; REYES, Y. Trichoderma spp. y su función en el control de plagas en los cultivos. Revista Protección Vegetal, v. 28, n. 1, p. 1-11, 2013.

MARTÍNEZ-MEDINA, A.; ALGUACIL, M. M.; PASCUAL, J. A.; VAN WEES, S. C. M. Phytohormone profiles induced by Trichoderma isolates correspond with their biocontrol and plant growth-promoting activity on melon plants. Journal of Chemical Ecology, v. 40, p. 804-815, 2014. http://dx.doi.org/10.1007/s10886014-0478-1

MAYMON, M.; MINZ, D.; BARBUL, O.; ZVEIBIL, A.; ELAD Y.; FREEMAN S. Identification of Trichoderma biocontrol isolates to clades according to ap-PCR and ITS sequence analyses. Phytoparasitica, v. 32, n. 4, p. 370-375, 2004. http://dx.doi.org/10.1007/BF02979848

MELO, I. S.; FAULL, J. L. Parasitism of Rhizoctonia solani by strains of Trichoderma spp. Scientia agricolae, v. 57, n. 1, p. 55-59. 2000.

MORALES, R. G. F.; SANTOS, I.; DANNER, M. A. Efeito do chorume líquido de suínos na podridão do colo e tombamento de plântulas de feijoeiro causadas por Sclerotium rolfsii. Fitopatologia Brasileira, v. 32, n. 5, p. 429-433. 2007. http://dx.doi.org/10.1590/S0100-41582007000500010

NAEIMI, S.; KHODAPARAST, S. A.; OKHOVVAT, S. M.; JAVAN-NIKKHAH, M.; VÁGVÖLGYI, C.; KREDICS, L.; KREDICS, L. Biodiversity of the genus Trichoderma in rice fields of Mazandaran province, Northern Iran and selection of potential biocontrol agents against the rice sheath blight pathogen Rhizoctonia solani. 3rd IFSDAA International Seminar on Crop Science for Food security, Bio-energy and Sustainability, Szeged, Hungary. 2010.

PAICA, A. In vitro interaction between Trichoderma asperellum isolate and other pathogenic fungi on corn. Romanian Journal for Plant Protection, v. 7, 2014.

PARMAR, H. J.; BODAR, N. P.; LAKHANI, H. N.; PATEL, S. V.; UMRANIA, V. V.; HASSAN, M. M. Production of lytic enzymes by Trichoderma strains during in vitro antagonism with Sclerotium rolfsii, the causal agent of stem rot groundnut. African Journal of Microbiological Research, v. 9, n. 6, p. 365-372, 2015. http://dx.doi.org/10.5897/AJMR2014.7330

PAULA JÚNIOR, T. J.; TEIXEIRA, H.; VIEIRA, R. F.; LEHNER, M. S.; LIMA, R. C.; QUEIROZ, T. F. N. Susceptibility of leguminous green manure species to Rhizoctonia solani and Sclerotium rolfsii. Summa Phytopathologica, v. 37, n. 4, p. 218-220, 2011. http://dx.doi.org/10.1590/S0100-54052011000400012

PEDRO, E. A. S.; HARAKAVA, R.; LUCON, C. M. M.; GUZZO, S. D. Promoção do crescimento do feijoeiro e controle da antracnose por Trichoderma spp. Pesquisa Agropecuária Brasileira, 2012, v. 47, n. 11, p. 15891595. http://dx.doi.org/10.1590/S0100-204X2012001100005

PINHEIRO, V. R. et al. Development of Sclerotium rolfsii sclerotia on soybean, corn, and wheat straw, under different soil temperatures and moisture contents. Pesquisa agropecuária brasileira, v. 45, n. 3, p. 332-334, 2010. http://dx.doi.org/10.1590/S0100-204X2010000300014

PUNJA, Z. K. Ecology and infection behavior of Sclerotium rolfsii Sacc. In: LYDA, S. D.; KENERLEY, C. M. Biology of sclerotial-forming fungi. Texas: The Texas Agricultural Experiment Station, 1993. p. 131-145. 
RASU, T.; SEVUGAPPERUMAL, N.; THIRUVENGADAM, R.; RAMASAMY, S. Trichoderma asperellum, identified as a novel fungal biocontrol agent for the control of plant pathogen. International Conference on Bioscience, Biotechnology and Healthcare Sciences, v. 14-15, p. 76-79, 2012.

SANMARTÍN, N. P.; LÓPEZ, X.; PEMBERTHY, M. P.; GRANADA, S. D.; RUEDA, E. A. Análisis del modo de acción y de la capacidade antagónica de Trichoderma asperellum sobre Colletotrichum gloeosporioides y Fusarium sp. Revista Tumbaga v. 7, p. 29-49, 2012.

SERRA, I. M. R. S.; SILVA, G. S. Caracterização biológica e fisiológica de isolados de Sclerotium rolfsii obtidos de pimentão no Estado do Maranhão. Fitopatologia Brasileira, v. 30, p. 61-66, 2005.

http://dx.doi.org/10.1590/S0100-41582005000100010

SHARMA. R. A brief review on mechanism of Trichoderma fungus use as biological control agents. International Journal of Innovations in Bio-Sciences, v. 2, n. 4, p. 200-210, 2012.

SOUSA, T. G.; BLUM, L. E. B. Uso de Trichoderma harzianum e condicionador orgânico de solo para controle da podridão por Sclerotium rolfsii em alho. Bioscience Journal, v. 29, n. 5, p. 1616-1623, 2013.

TAMURA, K.; STECHER, G.; PETERSON, D.; FILIPSKI, A.; KUMAR, S. MEGA6: Molecular evolutionary genetics analysis version 6.0. Molecular and Biological Evolution, v. 30, n. 12, p. 2725-2729, 2013. http://dx.doi.org/10.1093/molbev/mst197

WHITE T. J.; BRUNS T.; LEE S.; TAYLOR J. Amplification and direct sequencing of fungal ribosomal RNA genes for phylogenetics. In: PCR protocols: a guide to methods and applications. 1st ed. Academic Press, London. 1990. http://dx.doi.org/10.1016/b978-0-12-372180-8.50042-1

XU, Z.; GLEASON, M. L.; MUELLER, S.; ESKER, P. D.; BRADLEY, C. A.; BUCK. J. W.; BENSON, D. M.; DIXON, P. M. MONTEIRO J. E. B. A. Overwintering of Sclerotium rolfsii and S. rolfsii var. delphinii in Different Latitudes of the United States. Plant Disease, v. 92, n. 5, p. 719-724, 2008.

http://dx.doi.org/10.1094/PDIS-92-5-0719 